\title{
STORYTELLING AS A QUALITATIVE METHOD FOR IS RESEARCH: HERALDING THE HEROIC AND ECHOING THE MYTHIC
}

\author{
Julie E Kendall \\ Rutgers University \\ julie@thekendalls.org \\ Kenneth E Kendall \\ Rutgers University \\ ken@thekendalls.org
}

\begin{abstract}
We all like a good story, but as researchers we too often dismiss a story as being tangential or superfluous. In this paper we review how early adventurous information systems researchers attempted to use organizational stories in their work, but in doing so may have used mere fragments of stories as an alternative method to gathering data for the design, development, or documentation of information systems. From a theoretical perspective formed by the use of the social construction of technology, we reexamine the purpose or functions of myths and relate these to the functions of stories (which can be experiential, explanatory, validating, and prescriptive) and illustrate how myths are similar to the stories (that are normative or descriptive, practical or philosophical) we hear in organizations today. We explore the elements of a story and show why researchers need to be aware of not just the purpose of the organizational story (through elaboration of the myth), but also the telling of the story (through vividness) and the order in which the story is told (through the use of episodes). A researcher gleans understanding through storytelling by reacting, matching, eliciting, and collaborating with organizational participants, but above all the researcher must appreciate the story as a whole. In this paper we develop a new research method based on storytelling. In doing so we aim to inspire IS researchers to realize the depth and richness found in organizational stories and to appreciate and use stories in their own work.
\end{abstract}

Keywords: qualitative research methods; storytelling; social construction of technology; information systems research; narrative; myths; mythology; discourse analysis

\section{INTRODUCTION}

As children we get our first exposure to stories as fables. These early cautionary tales are stories that convey a lesson to young people. They warn about the consequences of adopting certain values (like the greediness of King Midas) or show by comparison that certain behavior will produce better results than other behavior (as in Aesop's fable of the "Ants and the Grasshopper").

Some stories are so good, that we hear them told and retold throughout our lives. Many organizational stories are like this too, taking on a life of their own. Stories originate in the workplace, and many are shared with, and repeated by, coworkers. Organizational stories, like myths and fables, are used for specific purposes. In the past, information systems (IS) researchers have dismissed these stories or even treated stories as if they impede data gathering. 
In this paper we explore early IS research using stories and story fragments, reveal what we learn from observing how researchers in other disciplines use storytelling, and adopt the tenets of social construction of technology (SCOT) theory as a useful lens for understanding organizational members' creation of shared meaning through IS stories. Realizing that organizational storytelling today is much like the telling of myths, we propose that researchers need to appreciate the story as a whole. We also assert that researchers need to identify the purpose, the telling, and the order in which the story is told. Our goal is to inspire IS researchers to realize the depth and richness found in organizational stories and to appreciate and use stories in their own work.

\section{Early Use of Storytelling in IS Documentation}

We can trace interest in IS and storytelling back to the days of mainframe computing. An early attempt that applied storytelling to solving information systems problems was proposed by Kendall and Losee (1986). They faced a legacy system with sketchy documentation and supplemented the manual with new, user-driven documentation they called FOLKLORE. Their approach asked users to contribute their thoughts and memories to create the information system's documentation (the result was not unlike the discussion and support forums like MacTalk or Microsoft Internet Explorer Forums that we have today in support of current software and computer products).

Their contribution, however, was to provide a unique form or structure for user contributions. Users were asked to contribute to one of four categories, which were based on those found in the Webster's New Collegiate Dictionary definition that folklore is "traditional customs, tales, sayings, or art forms preserved orally among a people,” (as quoted by Kendall and Losee, 1986).

Customs were stories about how people behaved. Tales were stories in the first person, where the teller was often the hero. Sayings were, according to Kendall and Losee, "distillations of tales," mainly brief exclamations, and the category of art forms was relaxed to include diagrams and flow charts found on bulletin boards and in file cabinets. Kendall and Losee noted that customs and tales were easier to obtain than sayings and art forms.

The FOLKLORE approach was later adapted for used on Macintosh computers using a hypertext system to link parts of the documentation for software together. This computer-based system was called SOFTLORE and encouraged contributors to freely add material in each of the four categories that would help users understand the system better (Kendall and Kerola, 1994).

\section{Storytelling in Information Requirements Analysis}

The following review of literature shows that systems analysts and information systems researchers have long believed that stories obscured, rather than revealed, critical information. Almost as a reflection of that perspective, interviewing evolved into a highly structured, almost ritualistic, data gathering approach. With that mindset, interviewers mistakenly discarded, overlooked, or downplayed the importance of stories, since they consumed valuable time.

Myers and Newman (2007) point out in their examination of qualitative interviewing in information systems research published from 2001-2005, using six articles chosen at random from MIS Quarterly, Information Systems Research, Journal of AIS, and Information and Organization for a total of 22 articles, that they found only two examples out of 22 that made mention of the types of questions posed and answers received. In other words even studies using the approach of qualitative interviews did not specifically mention what Myers and Newman asserted should be part of open ended questioning, i.e. "to focus on common, vividly-held events and stories," (p. 17). To further underscore the point, neither of the two studies they cite (Silva \& Backhouse, 2003 and Shim, Shin \& Nottingham, 2002) refers to elicitation of stories. While the Shim et al. paper published a list of 
questions used in interviewing; the authors do not make explicit mention of events or stories, asking instead about Internet "experiences."

Alvarez and Urla (2002) noted "While analysts may be inclined to dismiss narratives as messy or uncodeable data, the insights they provide merit attention," (p. 38). They continued, "Our interest in stories was sparked by their frequent dismissal by the analyst. Consultants often expressed frustration at storytelling and often dismissed it as trivial, irrelevant, or meaningless," (p. 42).

The scorn for stories was not limited to those in our field. As Denning (2000) recalled, "I quickly found that I was living in an age when storytelling was suspect. Scientists derided it. Philosophers threatened to censor it. Logicians had difficulty in depicting it. Management theorists generally ignored it,"(p. xv).

Sabherwal and Robey (1993), Boland and Schultz (1995), Kendall and Kendall, (1995), and later Brown (1998), who were all working in information systems research, noticed there was valuable information in the stories told by organizational members.

One problem with early research into stories was the focus on "data" gathering of fragments. The mindset that accompanied data gathering (before it slowly became information analysis) was to locate pieces of data, both physically in reports and memos, and orally in interviews. The aforementioned early authors tended to discuss fragments of narratives gleaned from interviews, rather than capturing an entire story. While they made a contribution by introducing stories into IS research, they stopped short of treating the story as a whole.

Often stories are discovered as part of an interview where other questions are asked. Moody, Blanton, and Cheney (1998) used a field study to compare interviewing techniques, using standard information requirements interviews with cognitive interviews. Cognitive interviewing, a method they described in detail, was "found to be more effective and more efficient than standard interviewing techniques in eliciting episodic knowledge from reference librarians," (p. 79). Working in the same era, Kelly and Zak (1999) noted that even though narratives excel at helping organizational participants make sense of reality, they are not used nearly enough.

Although still working with fragments, researchers have started to examine narratives in terms of interaction. Working in the domain of research into collaborative work systems, Pentland (1999) argued for conscious use of narrative features (drawn from Bruner, 1990) that go beyond the standard inclusion of "sequence in time" to include "focal actor or actors, identifiable narrative voice, and canonical or evaluative frame of reference in the study of collaborative work systems," (pp. 2-3). Pentland (1999) asserted, "to the extent that questions about collaborative systems are connected to questions about social interaction, however, narrative will be intrinsic to the phenomena of interest," (p.6).

More recently, Alvarez and Urla (2002) examined interview data to determine how stories function for participants in an ERP implementation. They noted that interviewees: organized their experience, sought to persuade listeners, and conveyed information to analysts using stories, habitual, and hypothetical narratives in their interviews (p. 38). They wrote, "That is, in this approach both interviewer and client are engaged in creating the meaning of the questions and answers that constitute the narrative as they negotiate understanding through language," (p. 40).

Fincham (2002) used stories taken from case study interviews to examine success and failure in systems development. In undertaking his study he noted about storytelling that, "the realm of social interpretation, however, has yet to be more broadly applied to systems or to the analysis of computer success and failure," (p.5). 
Kuechler and Vaishnavi (2006) used a series of experiments to determine the importance of including explicit goal-based information in narratives. Their goal was to improve the capability of decision support systems in supporting rapid, ad hoc decisions about dynamic business situations. They recommended designing systems using narratives that state goal information (why an action is taken), actors (who), activities (what is being done), temporal information (when), and means-ends (strategic information) along with presentation of "retrieved narrative so that the information is made more comprehensible and memorable.” (p. 974).

In summary, there are two observations that can be drawn from past research in IS that used storytelling. Firstly, the use of narrative in information systems research has been largely embedded in the context of studying IT practitioners eliciting information requirements or in capturing stories post hoc about documentation and systems implementations. In other words, IS researchers have predominantly used storytelling in a limited way to study aspects of the systems development life cycle. Our intention in this paper is to broaden the use of storytelling as a legitimate and useful research approach for studying information systems as organic systems, holistically within organizations.

The second observation is that, many of the stories that have been interpreted in IS research have turned out to be mere fragments of stories. The intent or purpose of the story is not reported and the reader is not able to fully understand the importance of the story as presented in the research. We believe that many of the stories discussed in IS research have been shared during the interviewing process yet the reader is not informed about whether this is an enduring story that others in the organization share and repeat, or whether it is an isolated story told in a single interview. Isolated stories are welcome when the researcher is looking for facts, while enduring stories capture all aspects of the organization, from practical to philosophical and from descriptive to normative.

Let's discuss and elaborate on these two observations in order. First, IS researchers need to focus more on systems holistically rather than pieces of systems (holons). At one time it was acceptable to use stories to find data for part of a systems lifecycle. Now the IS researcher needs to look at the organization, its members, its interactions, its purpose, how it manages to survive, and what good it does for society and individuals. A holistic approach to IS research is now possible and stories can help in this regard.

To understand the importance of a holistic approach, it can be beneficial for us to first understand how the appreciation of stories by researchers outside of the IS field has evolved. Early use of storytelling was modest in purpose. For example, Mitroff and Kilmann (1975) proposed that storytelling was a new tool for organizational problem solving. They claimed that companies could not exist without stories and thus they set the stage for more meaningful storytelling research. Weick and Browning (1986) furthered research in storytelling by observing that as narration changes, organizational structures change. Ready (2002) noted that storytelling can be used for building strategic competence and strengthening organizational character and Silverman (2004) showed that storytelling was used in communicating organizational strategy. Chreim (2005) observed that storytelling was useful in both continuing and changing organizational identity. In these later studies, the purpose of storytelling was clearly identified in a broader holistic context.

Our second observation concerns the fragmentation of stories as reported in IS research. We suggest that the entire story is greater than the sum of its parts. We assert that by analyzing the entire story as told, retold, shared, and passed down from one person to another, researchers will gain a deeper, more meaningful understanding of the organization and its members. 
In his retrospect and prospect article on IS research, Lee (2010) does a superb job of pointing out the importance of making a "major effort" to take a general systems approach such as that of von Bertalanffy (1968) or using Checkland's systems thinking approach (Checkland, 1999) for accomplishing future information systems research that would make systems concepts an essential "part of such an undertaking," (p. 345).

Once again we can learn from scholars outside of the field of IS. An early book by Tichy (1997) noted that storytelling was useful in creating emotional energy and energizing others. In a review of organizational storytelling, James and Minnis (2004) examined the role of stories in organizational culture; they looked at sense making and stories, as well as the managerial uses of stories. Hodgett and Deneulin (2009) observed that storytelling was useful in enriching human policy assessment. Barker and Gower (2010) championed "narrative paradigm theory" as a way to model storytelling as a complete organizational communication tool, using the diversity of the work environment to illustrate their argument. In these instances, the researchers searched for deeper meaning in enduring stories.

In sum, our purpose here is to promote the use of storytelling as a research method for IS researchers intent on analyzing and interpreting the social construction of technology (as discussed in the next section) concerning the use and management of IS in organizations through the stories that are told by organizational members. Unlike researchers who might use narrative analysis to study the narrative of a personal life story, a formal speech, a fragment of a story, or a printed text in order to study form and categories of the narrative (Lieblich, Tuval-Mashiach, and Zilber, (1998, p. 6), we specify the telling of a complete story as our unit of analysis (Moen, 2006).

Adopting a perspective grounded in sociocultural theory and using narratives to facilitate educational research on classroom behavior, Moen commented on the narrative as a unit of analysis, "Narratives are not broken into elements; they are neither reductionistic nor static," (Moen, 2006, p. 4). She concludes her study by stating, "I reiterate that narratives retain all the characteristics of the whole and that they occur as an integrated and living part of the whole. When appearing as a whole rather than elements, narratives are not abstract, remote, or inaccessible. Instead, they can rather be perceived as familiar, informative, and relevant for those who hear about or read them," (Moen, 2006, p. 9).

We propose storytelling as a qualitative research method. Our argument is supported by Boje (1991) who expanded on the importance of considering the text in conjunction with the telling or performing of a complete story:

The focus in traditional organization story research has been on texts ... these studies ignore performance and streamline the stories or treat them as so many variables that can give empirical explanations of the organization. The story telling organization theory posits story text and performance as two sides of the same coin and gives us insight into the complex and varied ways organization members use storytelling in their work world, (p. 125).

Therefore, in our approach to using storytelling as a qualitative method, we elicit a complete story as identified by both Moen (2006) and Boje (1991). In developing the research method, elements of a story that a researcher will be alert for are provided later in this article. Those elements can guide the researcher in capturing the telling of a complete story. The qualitative researcher who uses this approach is interested in the text of the story, the order in which the events are told, and the telling of the entire story by the organizational participant. This approach is distinct as it moves away from studying the text alone as previously suggested by Kendall, Kendall, and Kah (2007). These authors used dramatistic analysis to study the text of listserv messages rather than using the telling or performance of the story. 


\section{CONCEPTUAL FRAMEWORK}

The storytelling method we develop fits well within the interpretivist tradition as characterized by Creswell (2007), Gioia and Pitre (1990), Kaplan and Maxwell (1994), Klein and Myers (1999), and Walsham (1993). Gioia and Pitre (1990) noted, "The interpretive researcher collects data that are relevant to the informants and attempts to preserve their unique representations." They went on to add that analysis, the generation of theory and further data collection go hand in hand (p. 588). Additionally, Creswell (2007) stated in his account of how interpretive researchers proceed with their work by focusing on the "multiple perspectives of stories and who tells the stories," (p. 24).

In this paper we critically examine stories through the lens of the social construction of technology (Pinch \& Bijker, 1984) framework to understand how organizational stories are created among organizational participants and information systems researchers. We illustrate how IS researchers can identify how stories are functioning for organizational members. Examples of relevant organizational stories include descriptions of corporate culture and the use of information systems; revelations about how IT problems are solved; articulation of company values toward employees as well as toward adoption of new technologies; and promoting the image of the company as technologically ground breaking or the company's leader as technologically advanced.

We chose the social construction of technology (SCOT) as our lens because it is highly compatible with the purposes of the interpretive research we are conducting. As Myers (1997, updated November 12, 2011) noted, interpretive methods of research are "aimed at producing an understanding of the context of the information system, and the process whereby the information system influences and is influenced by the context"(Walsham 1993, pp. 4-5 as quoted by Myers). We believe the lens of the social construction of technology has the power to help us view and even magnify the process of technology adoption through the elicitation and examination of stories. In addition, SCOT is widely known, used, and understood by our intended audience, IS researchers. This type of ready recognition in the IS community furnishes many shorthand associations for those attempting to learn our new methodology. Indeed, while oft criticized, the social construction of technology approach still provides one of the dominant approaches to studying technological innovation ("Social Construction of Technology," n.d., para.1).

The social construction of technology (Pinch \& Bijker, 1984) framework is useful in understanding how the interplay of individuals, groups, and technology create shared meaning (in our case, stories) about technology processes and artifacts. The last 30 years or so have seen the development and use of the social construction of technology framework (MacKenzie and Wajcman, 1998; Misa, Feenberg, and Brey, 2003; Moisander and Eriksson, 2006; Pinch and Bijker, 1984; and Shin, 2006).

In basic terms, the social construction of technology (SCOT) proposes that technological innovations are constructed socially (negotiated) through human interactions taking place among individuals, organizations, and society. The four principles of the social construction of technology (as paraphrased from Pinch and Bijker, 1984) are: 1) interpretive flexibility, 2) relevant social groups, 3) closure and stabilization, and 4) technological frames, all of which we elaborate on in an upcoming section.

The IS researcher using SCOT looks for the negotiated meanings of technological innovations created by social processes. In our case, as IS researchers, SCOT is useful because it resonates with the interpretive research stance adopted here, and also it is widely recognized as a legitimate way to conceptualize technological innovation throughout the IS research community. The social construction of technology theory reminds us that information systems are usefully conceived as a coconstruction of meaning that result in a variety of IS artifacts, acceptable practices, actions to be 
taken, and alternative frames for sociological and technological thinking ("Social Construction of Technology," n.d., para.3).

The first principle of social construction of technology is that of interpretive flexibility, which visualizes technology design as an open process that results from negotiations within the group. According to Shin (2006, p. 86), when groups negotiate among themselves, different results are possible, depending on the social circumstances of development.

The second principle of social construction of technology says that meaning exists in the relevant social groups who create and abide by the same meaning of an artifact, story, or myth, by virtue of the fact that they exist in a shared social grouping. Since stories are often passed down person to person and even generation to generation, in this paper we focus on the shared social groupings implied by users and managers of IT within an organization and the meaning they impart to stories they tell and re-tell about technological artifacts. Indeed, the story itself can be considered an artifact, and a unit of analysis.

In the social construction of reality framework, features of closure and stabilization characterize the third element. How can inevitable conflicts within groups be resolved? This third principle of social construction of technology emphasizes the resolution of IS design conflicts. The end of a design phase is signaled when no social group brings up a problem with an artifact; i.e. the technological meaning is no longer the center of discussion. Following the phase of closure, the technological design can be characterized as frozen or stabilized, and the participants agree that the artifact, and the story about the artifact are in their final form (Shin 2006, p. 86).

In the fourth and final element of the social construction of reality framework we are working with technological frames. In the case of our organizational stories, we assume that this component reflects the shared exchanges or interactions of the group as they communicate with each other and the information systems researcher about the stories' widespread applicability.

SCOT informs our study by reinforcing the notion of conducting interpretivist research in IS. Since the first principle of SCOT is "interpretive flexibility" our storytelling method utilizes the principle of technology design as an open process that arises from negotiated meanings within a group. We leverage the second principle of SCOT, which is that of relevant social groups, in our storytelling method by interviewing shared social groupings comprised of users and managers of IT within a company. We use the third principle of SCOT, that of closure and stabilization, to understand where a story is in its life cycle; thereby identifying when an innovative technological artifact and the story about an artifact are in their final forms. Technological frames are the focus of the fourth and final principle of the social construction of technology approach. The IS researcher using storytelling from a SCOT perspective is actively seeking the technological relevance of stories being told.

For IS researchers, the four principles of SCOT encompass clear concepts to explore the questions of how stories of IT managers and users create shared meaning of information systems in a social context. Without SCOT, the IS researcher who is fortunate enough to identify a story may still be perplexed by it, with few ways to begin interpreting it. The theory of the social construction of technology helps us build our method of storytelling as an interpretive, qualitative approach that can be widely understood. 


\section{WHY STORYTELLING DIFFERS FROM NARRATIVE ANALYSIS}

\section{A Typology of Myths as being Useful in Organizations}

In this paper we draw much of our inspiration from the use of myths. Myths simply are stories (the word mythos is taken to mean plot by Aristotle (Doty 2004, p. 1)). Over time myths have accumulated and have also been passed on from generation to generation. Mythology is a repository for our knowledge in story form.

While there are many instances where MIS uses the term myth to refer to untruths (Denning, 2004; Grover \& Ramanlal, 1999; Mintzberg, 1972; Powers \& Dickson, 1973; Seffah \& Metzker, 2004; and Vergin \& Grimes, 1964), we return to the classic meaning of the term myth. We agree with Doty (2004), who objects to what is seen as a misappropriation of the word myth.

On the other hand, myths are complex narratives, not simple folktales or song-texts, by which human cultures stabilize and encode their deepest ambiguities" (Robinson 1993: 136). They are "deep stories" of a culture (Wagner and Lundeen 1998: 3) that reflect the human tendency to organize its representation of the past, present, and future according to specific emphases and moral highlights. (Doty 2004, p 13)

The classical concept of the myth is critical to the development and enrichment of the storytelling method we are proposing. Myths are stories that are deep and enduring. Myths represent the shared belief of people within a society (or in our case, members within an organization). Myths can address the past, the present, or the future by telling the listener how things have been (Levy, 1994), why we behave a certain way (Belk \& Tumbat, 2005), how to behave (Whelan \& O'Gorman, 2007), or even what happens if we fail to act in a certain way (Livingston, 1965).

Stories take on mythic qualities when they represent a shared vision, are carefully retold, and passed to the next generation. Over the years, the authors have heard many mythic stories when they visited organizations. We assume therefore that knowledge of myths can help us in the development of the storytelling method contained in this article.

Joseph Campbell has written extensively on the use, meaning, and purpose of myths (Campbell, 1964) and discussed in detail four functions of myth. The four functions were summarized succinctly by Young (2004). They are: 1) a metaphysical function, 2) a cosmological function, 3) a sociological function, and 4) a psychological function. The metaphysical function describes awakening and experiencing the awe of the universe. The cosmological function explains how the universe is organized. The sociological function validates and maintains the social order. The psychological function turns to the individual and directs how an individual should behave. Occasionally this fourth function appears as the pedagogical function.

We find Campbell's four functions to be a good starting point in the development of a typology of organizational stories. We observe that Campbell's four functions of myth can be said to correspond to storytelling in organizations and identify four functions of common stories as follows:

1. The experiential function. Stories that describe experiencing what the organizational universe is like.

2. The explanatory function. Stories that attempt to explain the organizational universe.

3. The validating function. Stories that try to maintain the organizational value structure.

4. The prescriptive function. Stories that recommend correct and proper behavior in the organization. 
Table 1 compares Campbell's functions of myth with storytelling functions that we based on Campbell's work. The concepts are similar but the researcher should be able to relate more with the storytelling functions we've identified.

\begin{tabular}{|l|l|l|l|}
\hline $\begin{array}{l}\text { Campbell's } \\
\text { (1964) Myth } \\
\text { Functions }\end{array}$ & $\begin{array}{l}\text { Young's (2004) Description } \\
\text { Of Each Myth Function }\end{array}$ & $\begin{array}{l}\text { Storytelling } \\
\text { Functions } \\
\text { Defined Here }\end{array}$ & $\begin{array}{l}\text { Description of the Story } \\
\text { as it Relates to Modern } \\
\text { Organizations }\end{array}$ \\
\hline Metaphysical & $\begin{array}{l}\text { Describes awaking and } \\
\text { experiencing the awe of the } \\
\text { universe }\end{array}$ & Experiential & $\begin{array}{l}\text { Stories that describe } \\
\text { experiencing what the } \\
\text { organizational universe is } \\
\text { like. }\end{array}$ \\
\hline Cosmological & $\begin{array}{l}\text { Explains how the universe is } \\
\text { organized }\end{array}$ & $\begin{array}{l}\text { Explanatory } \\
\text { Sociological }\end{array}$ & $\begin{array}{l}\text { Validates and maintains the } \\
\text { social order } \\
\text { explain the organizational } \\
\text { universe. }\end{array}$ \\
\hline $\begin{array}{l}\text { Psychological } \\
\text { (Pedagogical) }\end{array}$ & $\begin{array}{l}\text { Directs how an individual } \\
\text { should behave }\end{array}$ & Prescriptive & $\begin{array}{l}\text { Stories that try to maintain } \\
\text { the organizational value } \\
\text { structure. }\end{array}$ \\
\hline $\begin{array}{l}\text { Stories that recommend } \\
\text { correct and proper } \\
\text { behavior in the } \\
\text { organization. }\end{array}$ \\
\hline
\end{tabular}

Table 1. How Campbell's Functions of Myths Relate to the Functions of Storytelling

The first function of organizational storytelling, the experiential function, examines experiencing the business universe. These stories retell the observations of the storyteller, who describes what the business world is all about. The emphasis is on experiencing the organization, not in trying to understand it. The storyteller doesn't try to explain why something happens; rather they tell a tale that describes how things unfold. The ability of the group of people coming together to create something is told but not questioned. Qualitative researchers understand this concept. Examples of the experiential function shown in Table 2 use stories to describe corporate behavior (Smillie, 2010), use stories to enhance camaraderie (Berman, 1995), and use stories to encourage social inclusion (Gillard, Mitev, and Scott, 2007).

The explanatory function, the second function of organizational storytelling, looks a little deeper into how an organization works. Examples of the explanatory function are stories that reveal how problems were solved (Vlachoutsicos, 2011), stories that analyze culture and behavior (Mascarenhas et al., 2010), and stories that explain why certain decisions were made (Frohman, 2006).

The third function of organizational storytelling is the validating function. These stories are told to support the organization, its structures, and its decisions. Validating stories seek to maintain the existing value structure. In validating the way the organization behaves, they seek to preserve the organization well into the future. The main difference between the third function and the previous two is that the validating function is normative, while both the experiential and exploratory functions are descriptive. Examples of the validating function include stories that articulate company values (Mainiero, 1994), stories that manage change or even slow it down (Macaulay, Yue, \& Thurlow, 2010), and stories that extend corporate knowledge (Stewart \& Kaufman, 1995). 


\begin{tabular}{|l|l|l|}
\hline $\begin{array}{l}\text { Storytelling } \\
\text { Function }\end{array}$ & $\begin{array}{l}\text { Common Stories Found } \\
\text { in Organizations }\end{array}$ & Example Found in the Literature \\
\hline \multirow{3}{*}{ Experiential } & $\begin{array}{l}\text { Describing corporate culture } \\
\text { Enhancing team camaraderie } \\
\text { Encouraging social inclusion }\end{array}$ & $\begin{array}{l}\text { Smillie (2010) } \\
\text { Berman (1995) } \\
\text { Gillard, Mitev, and Scott (2007) }\end{array}$ \\
\hline \multirow{3}{*}{ Validating } & $\begin{array}{l}\text { Revealing how problems are solved } \\
\text { Analyzing culture and behavior }\end{array}$ & $\begin{array}{l}\text { Vlachoutsicos (2011) } \\
\text { Mascarenhas et al. (2010) }\end{array}$ \\
& $\begin{array}{l}\text { Articulating company values } \\
\text { Managing or slowing down change } \\
\text { Extending corporate knowledge }\end{array}$ & $\begin{array}{l}\text { Macaulay, Yue, \& Thurlow (2010) } \\
\text { Stewart and Kaufman (1995) }\end{array}$ \\
\hline \multirow{2}{*}{ Prescriptive } & $\begin{array}{l}\text { Educating future decision makers } \\
\text { Changing or controlling behavior } \\
\text { Promoting image of the company }\end{array}$ & $\begin{array}{l}\text { Désilets (2008) } \\
\text { Higgs and Rowland (2010) } \\
\text { Hanson (2004) }\end{array}$ \\
\hline
\end{tabular}

Table 2. Common Stories Found in Organizations Fall into One of Four Functions

The prescriptive function, the fourth function of organizational storytelling, regulates how individuals and the company as a whole should behave. The storyteller directs the listener and might go so far as to prescribe certain activities that must be done in the future. Occasionally this story could be told as a cautionary tale, warning of dire consequences if an individual doesn't act a certain way, or it can be told as a simple parable. In any case, this type of storytelling is normative. Examples of the prescriptive function in an organizational setting are stories that educate future decision makers or leaders (Désilets, 2008), stories that help in changing or controlling behavior (Higgs \& Rowland, 2010), and stories that promote the image of the company or leader (Hanson, 2004).

Figure 1 depicts the differences among the four functions served by organizational stories by separating the experiential, explanatory, validating, and prescriptive functions into one of four quadrants. They are drawn as existing on an axis that runs from practical to philosophical (top to bottom) and from descriptive to normative (right to left). On the practical side of the continuum we hear stories recommending actions such as educating, describing, and controlling, while on the philosophical side we hear stories that explain, analyze, reveal, and articulate concepts rather than actions. On the normative side of the continuum, we hear stories that tell listeners how to act, while on the descriptive side we hear stories that describe how things are.

Notice that stories performing an experiential function for their tellers are thus categorized as most practical and most descriptive, while stories that serve the explanatory function are descriptive and philosophical. Stories serving a validating function are categorized as normative and philosophical, while in the fourth quadrant, stories serving the prescriptive function are described as practical and normative. The benefit of developing and sharing this typology with researchers is that the researcher who is familiar with the typology is more likely to understand the context from which the stories emerge. Contextualization is a key principle in interpretive field research. 
Based on our work in organizations, we recognize that most organizational stories feature a hero wherein the storyteller often identifies herself or himself as the hero or protagonist who experiences a struggle only to come up with a positive solution to a problem. There are, however, occasional negative stories that have the potential to do damage and are persistent.

Some examples of negative stories are stories that make the mythmaker or storyteller the center of the business universe (experiential), stories that exclude or stereotype people or groups (explanatory), stories that encourage behavior that deviates from the norm (validating), and stories that attempt to negatively modify behavior (prescriptive).

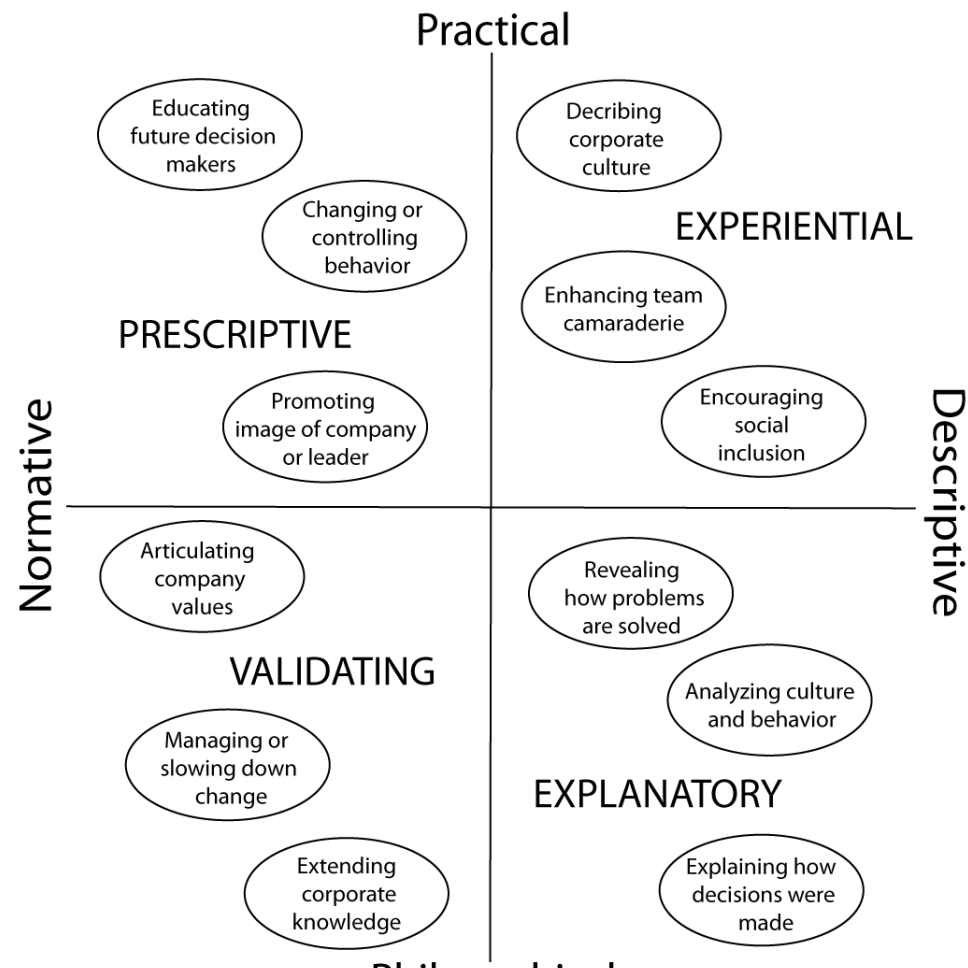

\section{Philosophical}

Figure 1. Organizational stories serve one of four functions (experiential, explanatory, validating, or prescriptive).

The four functions of storytelling distinguish it from other information gathering methods. A key practice for IS researchers using the story method is to identify the function a story is serving for organizational participants. Analysis progresses as the function of a story is identified.

Understanding the four functions of storytelling is useful to the researcher for many reasons. First it helps the researcher put stories into context. Functional context is just as important as historical or social context. Second, knowledge of storytelling functions reminds the researcher that they themselves may also harbor preconceived notions about stories as they are told. Third, understanding the functions of storytelling can explain why the storyteller often describes himself or herself as the hero of the story. Fourth, understanding storytelling functions can explain why different participants tell the same story in different ways. 
The storytelling method encourages the researcher to revise their initial understanding of the informing narrative based on several stories collected from participants. When researching why information systems fail, the IS researcher using this storytelling methodology may be drawn to interview participants in an organization with a high rate of system failure based on a preconception that several new systems implemented in the organization have failed due to resistance to change in the organization.

After collecting several stories from participants, the researcher may revise their conception repeatedly thus revising their main impression in the process. For example, one person's narrative may feature a story that makes the operations department the hero because of their championing of new technology, specifically their use of supply chain management applied to services; another may share a narrative that they are convinced that a new IS will radically alter the company's external relationships, while a third person's story may highlight fears associated with implementing a new supply chain management system too rapidly.

In response to these findings in the field, the researcher using the storytelling method may revise their central concept, moving to examine alignment of new information systems with overall organizational strategic goals, and in this way revising their initial, narrower theoretical conception of resistance to change.

\section{The Elements of a Story}

Researchers who embrace storytelling as a research method also need to understand the basic elements of a story. The following is a guide that explains commonalities found in complex stories. It lists 18 elements, each followed by a description. The 18 elements were compiled by the authors from their experiences in organizations, observations about stories and plots in theatre productions, and a continuing discussion about stories and myths with playwrights they have met. ${ }^{1}$ Common elements of stories include:

1. Mythical Quality. Stories that have an enduring quality have a larger meaning. They take on a mythic quality.

2. Call to adventure. Every story has a call to adventure. This can be a crisis, a trigger, or an opportunity.

3. The hero. Every mythical story has a protagonist.

4. The goal is revealed. A hero is assigned a quest.

5. Hero's inner problem surfaces. A complex story reveals both a hero's outer and inner problems. Outer problems are observable challenges and obstacles obvious to all of us. Inner problems describe challenges to the hero such as learning about oneself.

6. A new situation arises. A complex story will describe the hero leaving their normal world and entering a new world that may have different rules, expectations, and timetables.

7. The hero is tested. Along the way, the hero will be challenged.

8. Enemies or forces of nature intervene. The hero may encounter enemies or forces of nature that need to be overcome.

9. Hero encounters new obstacles. In addition, certain obstacles may need to be overcome as well.

10. Hero experiences a transformation. The hero may experience an ordeal, may receive a brilliant idea, and may even experience a change along the way.

11. Hero experiences a setback. The story may detail a series of failures along the way.

12. Hero may be deceived. The hero may experience deception on their journey.

13. The situation is resolved. At some point there is a resolution. Either the hero fails (and metaphorically dies) or the hero succeeds.

14. Lessons are learned. In either case, there are lessons learned.

15. Better problem understanding. The hero or someone else now understands the problem better and will hopefully succeed (especially if the hero experiences failure). 
16. Quest is easier next time. In the future, the hero or someone else might encounter a similar problem but will have an easier time succeeding.

17. Celebration time. Often the story ends with recognition and joy.

18. Epilogue. Sometimes a story ends with an epilogue where the storyteller will explain what has happened since the problem was resolved.

Examples of each of the above elements are given in Table 3 later on in this paper.

There are numerous reasons that stories linger in the memories of those who hear them. Human beings are equipped with special capacities to recall stories, read into them in personally meaningful ways, and efficiently store information in the form of episodes that can be recalled later. Stories involving organizations can be just as memorable as myths and legends because organizational stories have similar characteristics to myths.

There are three mechanisms that distinguish storytelling from narratives. Researchers Swap, Leonard, Shields, and Abrams (2001) suggest that these three underlying cognitive mechanisms aid people in remembering the stories have heard earlier to then use them in appropriate situations. The three cognitive mechanisms are 1) the availability heuristic (also called the vividness effect), 2) elaboration, and 3) episodic memory. They are important because they provide the abstractions needed so that the researcher interprets the story as a whole, rather than trying to interpret the 18 elements.

In the availability heuristic, listeners hear a story that is memorable because it is told vividly via a story that they remember. In the elaboration mechanism, the listener is given enough detail so that the story is meaningful to them in their own experience. They can elaborate the story from their own background, and thus have an easier time remembering it. Episodic memory refers to the idea that it is easier for listeners to recall information organized in a story or episode than it is to try and remember a list of items without the context provided.

The elements of a story we outlined above exhibit all three of these mechanisms. First it is complex. Each of the 18 elements makes a unique point that is similar to a myth or fable the listener is familiar with (vividness). Next, the story is told in such a way, that the listener can empathize, or even identify with, the hero (elaboration). Finally, it is complex enough to have 18 scenes or episodes that are witnessed in an unmistakable and crucial order (episodic).

So in using storytelling as a research method, the researcher needs to appreciate the entire story and to be aware of the telling (through vividness), the purpose (through elaboration of the myth), and the order (through the use of episodes). These three mechanisms emphasize why using storytelling as a research method differs from other types of narrative analysis that focus on the analysis of transcribed interviews, or on the examination of reports, blogs, email, and other text found in organizations.

An illustration of how a storyline is used in an organizational setting is found in Table 3 . The story elements are mapped to events and plot points from a situation that occurred from a 5.9 magnitude earthquake near Whittier, California in 1987. This story appeared in an abbreviated form in an article about disaster recovery planning for an organization's software, data, and systems (Kendall, Kendall, and Lee, 2005). The authors recommended that organizations adopt a workshopping metaphor from evolving theatre practices. In this article we break down the story about an earthquake, a heroic IT team leader, and a plot involving ATMs (an abbreviation for automated teller machines; also known as cash points) into segments and match them to the elements that are common to all stories.

Table 3 provides a roadmap for the interpreter to follow, but if each element was taken alone, it would not be representative of the story as a whole. Here is where the three mechanisms come in. They provide the abstraction needed so that the interpreter can understand the entire story. The mechanism of vividness provides realism and a comparison to other experiences the researcher has had, the mechanism of elaboration helps identify the function so that the researcher can better understand the 
purpose of the story, and the mechanism of episodes helps the researcher understand the order in which the story is revealed.

\begin{tabular}{|c|c|}
\hline Story Element & Example from Whittier Earthquake ATM Problem \\
\hline Mythical Quality & Our company is a family so we work together. \\
\hline Call to adventure & $\begin{array}{l}\text { A } 5.9 \text { magnitude earthquake struck Whittier, east of Los Angeles on } \\
\text { October } 1,1987 \text {. }\end{array}$ \\
\hline The hero & The IT department came to the rescue. \\
\hline The goal is revealed & The ATM machines in the area are down and need to be restored. \\
\hline $\begin{array}{l}\text { Hero's inner problem } \\
\text { surfaces }\end{array}$ & The team leader never worked under such time pressures. \\
\hline A new situation arises & The team had to evacuate the building. \\
\hline The hero is tested & The phone lines were down. How could he communicate? \\
\hline $\begin{array}{l}\text { Enemies or forces of } \\
\text { nature intervene }\end{array}$ & $\begin{array}{l}\text { Other banks would steal customers if ATM machines were not } \\
\text { restored. }\end{array}$ \\
\hline $\begin{array}{l}\text { Hero encounters new } \\
\text { obstacles }\end{array}$ & The power lines went down as well. \\
\hline $\begin{array}{l}\text { Hero experiences a } \\
\text { transformation }\end{array}$ & $\begin{array}{l}\text { The team leader realized that an employee had a cell phone (rare in } \\
\text { 1988). Coordinated and communicated with others. }\end{array}$ \\
\hline Hero experiences a setback & No one was allowed to enter the building. \\
\hline Hero may be deceived & (Did nor occur in this story.) \\
\hline The situation is resolved & $\begin{array}{l}\text { At the last minute (as payday arrived) power was restored and } \\
\text { access to the building was allowed. }\end{array}$ \\
\hline Lessons are learned & $\begin{array}{l}\text { Store data off-site. Appoint an IT team member to examine disaster } \\
\text { scenarios, organizational resources, forecasts, and the } \\
\text { interconnectedness among them. }\end{array}$ \\
\hline $\begin{array}{l}\text { Better problem } \\
\text { understanding }\end{array}$ & The IT staff realized that it does not control everything at all times. \\
\hline Quest is easier next time & $\begin{array}{l}\text { Anticipating problems and planning for them will help the } \\
\text { coordination of the recovery efforts. }\end{array}$ \\
\hline Celebration time & $\begin{array}{l}\text { ATMs were restored in time for Friday payday. It is unlikely that } \\
\text { the bank lost customers. }\end{array}$ \\
\hline Epilogue & $\begin{array}{l}\text { New regulations stipulate that banks must store data at off-site } \\
\text { locations at least } 100 \text { miles away. }\end{array}$ \\
\hline
\end{tabular}

Table 3. Storyline example from the 1987 Whittier Narrows Earthquake.

\section{USING STORYTELLING AS A RESEARCH METHOD}

\section{Developing the Method}

When using storytelling as an approach, the IS researcher might identify stories through informal interactions, or identify stories appearing in interviews or corporate literature such as websites or advertising campaigns. Unlike interviews, that customarily take place in offices and meeting rooms, the process of obtaining stories can also take place in cafeterias, parking lots, warehouses, and shipping docks. These stories can be documented and can serve as the basis for reacting, matching, or eliciting performances of stories, or collaborating on a story with organizational participants. These activities form the basis for eliciting information in the proposed new method. Recall that when 
storytelling is used as a qualitative method, the IS researcher is using the story as the unit of analysis (Moen, 2006, p.2).

Interaction between the researcher and the participants will have an effect on the data that the researcher obtains and the storytelling method recognizes that the participants are in many cases both storytellers and interpreters while the researchers are sometimes co-contributors to stories as well as interpreters. In seeking stories, the researchers want more than a description of a procedure or a description of how a problem was solved. They are therefore required to interact with the participant so that they can obtain richer, more meaningful stories. Four interactive story activities researchers can be involved in, include reacting, matching, eliciting, and collaborating.

Reacting means the IS researcher is requesting reactions to events or data learned through other methods. For example, the researcher might say, "Now that you, as a member of the company, have seen this data, what is a story you would tell to respond to this event?"

Matching means that the researcher asks for a "matching" or "bookend" story that mirrors a story or incident provided. For example, the researcher might say, "Here is a story about the push for more and more advanced use of IT in a company. Please tell a story that reveals your own reaction to the significance of increasing IT budgets on an annual basis."

Eliciting means that the researcher is consciously communicating with an organizational member to request information in the structure of a story. For example, the researcher might say, "Tell me a story about the time you created a workaround to get your work done when the system went down and you were trying to meet a deadline."

Collaborating with organizational participants in the creation of a meaningful story is a distinct aspect of storytelling as a qualitative research method in that it demands that the researcher be functioning on a very high level of proficiency, sophistication, and honesty and that they can contribute both technical and soft skills to collaboration efforts. Take for example the story about the Whittier Narrows Earthquake that appears in Table 3. The researcher could participate in the research because they knew facts about the earthquake. In this instance, the story became richer than if it were simply told by a single storyteller.

The interaction described above will undoubtedly have an effect on the story being told, but we already know that any story will change to some degree depending on the audience. Even a carefully structured story such as The Agony and Ecstasy of Steve Jobs, told by the author monologist Mike Daisey, changes from night to night depending on the reaction of the attendees (personal discussion with Mike Daisey, 23 October, 2011, New York City, USA). The researcher must therefore assume that the storyteller will tell a story a certain way while in front of the researcher. In order to better understand how a story is told, the researcher needs to be aware of and apply the above four interactive story activities, not only to obtain richer and deeper stories, but also to be more cognizant of the effects of the interaction between the participant and researcher.

The first two interactive story activities can be used to guide the participant into telling a story on a particular topic and have less effect on the stories than the other two activities. Eliciting, the third story activity seeks more details from the participant and is therefore more intrusive.

Johnson (2008) gives a prime example of eliciting a story, when she wrote about storytelling and software testing, noting she asks software testers that she hires:

Have you seen bugs you can't reproduce? Do you think there are issues still lurking in this product? Are there bugs you haven't reported because you know the bugs that cannot be reproduced will be disregarded? Give me your impressions. I often ask the testers I hire - I ask direct hires, contractors 
and outsourced teams that I've managed - what are your impressions. I guess what I've been asking for is, tell me a story. Tell me about your experience with the software.

Eliciting will obtain information on the specific details the researcher is looking for, but caution is advised as the story must change dramatically to include what the storyteller thinks are sub-plots.

Collaborative storytelling places the researcher in a creative partnership with the organizational participants and therefore is the activity that involves the most interaction. Often the activity of storytelling can be accomplished orally in a group, team, or panel setting rather than one-on-one. In this way, the participants are free to do what is called "fantasy theme chaining" (Bormann, 1972), building on each other's comments to collectively create a hero, place blame on a villain, solve problems, or resolve the tensions of situations encountered with information systems. 2

\section{HOW STORYTELLING DIFFERS FROM OTHER QUALITATIVE APPROACHES}

It is useful to examine how storytelling is distinct from other types of familiar qualitative approaches in information systems research. While researchers may initially be attracted by similarities between storytelling and other methods such as narratives, interviewing, discourse analysis, observation, and therefore find it appealing, it is also wise to become cognizant of the distinct facets of storytelling as a method in its own right.

In this section we briefly compare and contrast interviewing, discourse analysis, metaphors, and observation with the storytelling approach proposed here, surfacing some advantages of the storytelling method in contrast to more familiar narrative approaches. Denning (2000) observes "The narrative way of thinking is internal and immersive and self-forgetting and attached to the full richness of tacit understanding. Through a story, life invites us to come inside as a participant," (p. 70).

Interviewing is a mainstay for data gathering in information systems research (Schultze and Avital, 2011). The investigative stance or perspective of the IS researcher is typically one of elicitation: seeking opinions, feelings, organizational and personal goals, and informal procedures. These are often fragments of stories, not complete stories. The researcher also needs to draw out opinions about human-computer interactions and ergonomics of the system including usability, pleasantness, enjoyment of use, and how well the system supports accomplishment of individual tasks (Kendall \& Kendall, 2011, pp. 103 and 104). But in order to do so, interviewing has become more structured over time, for example see the work of Tan and Hunter (2003). While this allows for easy comparison among participants and organizations, the increased structure may not allow the participants to tell their own stories. Personal priorities and key impressions may remain hidden. Myers and Newman (2007) summarized previous research and explained several of the pitfalls in using the qualitative research interview (p. 4).

Discourse analysis begins with text and narratives, but tends to break texts and conversations into manageable pieces suitable for analysis. This approach is evident in the work of Ellingsen (2003) who studied the development of knowledge work in hospitals in Norway. In another study, Dube and Robey (1999) interpreted narratives that emerged from a software project and the complexity of negotiating multiple perspectives. One problem is that discourse analysis does not show concern for the order in which statements are made. This order is essential in the telling of a story. Furthermore, Boland and Schultze (1996) suggested that although one narrative may be convincing, there is always an alternative narrative waiting to step in as the prevailing narrative.

Information systems researchers often identify, gather, analyze, and interpret metaphors (which are figures of speech that assert that one thing is another, e.g. an organization is a well-oiled machine) as 
a way to understand and interpret what is happening with information systems in an organization; as a way to understand information systems development methods; as well as a way to interpret organizational settings (Kendall \& Kendall, 1993, 1994). An approach seeking organizational metaphors is indeed a valid approach since it attempts to view a different dimension of the organization. However, using metaphorical analysis is complex and time-consuming. It is also possible to miss the subtler metaphors that occur daily in organizations.

Observation is an important method for eliciting information. Unless observation is structured, it can also be selective, similar to the fragmentation in interviews. Researchers and management consultants alike have been following around decision makers for decades. They can observe and document their behavior with the analyst's playscript, a document that describes each action taken by each organizational member (Shultis, 1964). In the UML (the Unified Modeling Language) exceptions to main activities are documented in use case scenarios (Jacobson, Booch, and Rumbaugh, 1999). STROBE, Structured Observation of the Environment (Kendall \& Kendall, 1984a, 1984b, and 1985) is an unobtrusive method for observation that looks at common physical elements in an office to determine the use of information by executives. Still, observation has its limits. Would you prefer to observe Einstein, or listen to his stories? A comparison of the above methods can be found in Table 4 .

\begin{tabular}{|c|c|c|}
\hline Method & Strengths & Weaknesses \\
\hline Storytelling & $\begin{array}{l}\text { The story as a whole is greater than the } \\
\text { sum of its parts. } \\
\text { Knowing intended function of the story } \\
\text { gives more context. } \\
\text { - Stories that possess vividness, } \\
\text { elaboration and episodic order are } \\
\text { long-lasting. } \\
\text { - Stories can be handled down (as } \\
\text { myths) from organizational generation } \\
\text { to generation. }\end{array}$ & $\begin{array}{l}\text { - Requires the researcher to learn about } \\
\text { storytelling. } \\
\text { - Print-based journals cannot print entire } \\
\text { story. } \\
\text { - Requires the researcher to interact, thus } \\
\text { changing the story or its effect. } \\
\text { - Stories may be true, untrue, or partially } \\
\text { true. }\end{array}$ \\
\hline Interviewing & $\begin{array}{l}\text { Excels at obtaining opinions, feelings, } \\
\text { organizational and personal goals, and } \\
\text { informal procedures. } \\
\text { - Can be managed and structured. } \\
\text { - Makes it easy to compare participants } \\
\text { or organizations. }\end{array}$ & $\begin{array}{l}\text { - Tends to result in obtaining fragments of } \\
\text { stories. } \\
\text { - Has a tendency to be too structured. } \\
\text { - Participants may not have the opportunity } \\
\text { to tell the stories they want to tell. }\end{array}$ \\
\hline $\begin{array}{l}\text { Discourse } \\
\text { Analysis }\end{array}$ & $\begin{array}{l}\text { - Views language as social interaction. } \\
\text { - Can be aware of the social context in } \\
\text { which discourse occurs. } \\
\text { - Emphasizes naturally occurring } \\
\text { language. }\end{array}$ & $\begin{array}{l}\text { - May ignore the order in which statements } \\
\text { are made. } \\
\text { - Can become too mechanical unless care is } \\
\text { taken. } \\
\text { - Focuses more on text than actions or } \\
\text { cognitive maps of participants. }\end{array}$ \\
\hline Metaphors & $\begin{array}{l}\text { Excels in understanding the social and } \\
\text { historical context. } \\
\text { - Can explain which Information system } \\
\text { is likely to succeed or fail. }\end{array}$ & $\begin{array}{l}\text { - Difficult for some researchers who have } \\
\text { difficulty identifying predominant } \\
\text { metaphors. } \\
\text { - Listening for and identifying metaphors is } \\
\text { time-consuming. }\end{array}$ \\
\hline Observation & 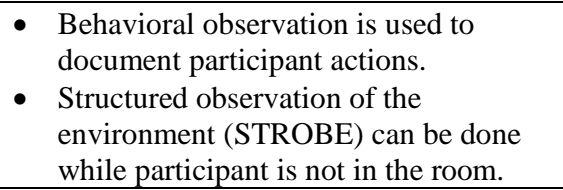 & $\begin{array}{l}\text { - Behavioral observation is intrusive and } \\
\text { time-consuming. } \\
\text { - STROBE is effective and negating the } \\
\text { narrative but is less effective at confirming } \\
\text { the narrative. }\end{array}$ \\
\hline
\end{tabular}

Table 4. Strengths and weaknesses of five types of information gathering methods 


\section{CAVEATS AND LIMITATIONS OF STORYTELLING AS A RESEARCH METHOD}

As is the case with the use of any research approach, be it a qualitative method or not, certain caveats apply to the use of storytelling. They include:

1. Storytelling as a qualitative research method for IS researchers is best used in conjunction with other research methods (i.e., using a multiple methods approach to avoid the limitations listed in Table 4).

2. Fruitful application of storytelling as a qualitative research method requires full participation of the organizational members involved.

3. The researcher needs to reveal the stories, not just fragments to the reader and to follow a method as suggested.

4. The act of storytelling as a qualitative research method engaged in by IS researchers demands honesty from the researcher as well as organizational participants.

We now discuss each of the four caveats in more detail. We underscore the importance and worthiness of a multiple methods approach (Patton, 2002), which will allow the weaving of a bright tapestry rather than spinning of one single strand. An IS researcher relying solely on stories is unlikely to accomplish all of their research goals. For example, some compelling narratives will not unfold accurately, or even be comprehensible, without the benefit of quantitative performance reports or monthly sales figures, as another way to understand the story.

As Denning (2000) points out, "Storytelling doesn't replace analytical thinking. It supplements it by enabling us to imagine new perspectives and new worlds, and is ideally suited to communicating change and stimulating innovation. Abstract analysis is easier to understand when seen through the lens of a well-chosen story and can of course be used to make explicit the implications of a story," (p. xviii).

When a researcher seeks meaningful interpretation of stories told by organizational members, the company participants must be fully on board. This might entail creating a longer timeline for project completion, since learning storytelling could require special types of coaching, as well as the development and use of instructive templates, websites, and seminars dedicated to heightening awareness of the importance of storytelling to the IS function (Ohara and Cherniss, 2010).

Storytelling research has been problematical for many print-based journals, because of the demands of lengthy passages and unusual grammatical notations. Typically authors and journals in the past have resorted to quoting fragments of stories, not complete ones. Instead, authors can provide links in their papers that send the reader to their own research sites and data (a policy that federal granting institutions in the US are now requiring), which can in turn display entire stories. As storytelling in IS becomes more widely adopted, IS editors and reviewers will doubtless adjust to the demands of accommodating lengthier pieces.

Using a storytelling approach requires both individual and organizational candor, which is not apparent, possible, or (as some would say) even desirable in all settings. For the researcher's part, they must heed the ancient Greeks advice of "Know thyself," in order to harbor the substantial selfawareness necessary to interpret stories in a way that is meaningful to organizational participants as well as the IS researcher. Just as there are reasons participants tell their stories, researchers have reasons for interpreting them as they do. They need to be aware of their prejudices when they begin the study. Gabriel (2000) explained, "The most evident danger of story-based research is the selective use of organizational narratives to amplify or reinforce the researcher's preconceived ideas or assumptions," (p.151). 
It is wise to remember that the presence of the IS researcher using qualitative research methods changes the organization. For researchers involved in precipitating stories, this idea of the interactions among the researcher, the study organization, and any change in information systems should shape and inform the IS researcher's behavior from the outset. The caveats and limitations outlined in this section provided could spur many new research questions that provide ample substance for future studies.

So, in essence the storytelling method consists of the following:

1. The main point of the storytelling method is to realize the whole story is greater than the sum of its parts. Realizing that there are parts common to every story (as represented in our typology of 18 story elements) is useful to understanding the whole, and understanding the whole helps explain the reason why specific actions occurred.

2. The mechanisms of vividness, elaboration, and episodic order are useful for the researcher in the process of abstraction. These three mechanisms help explain why a story may take on mythic qualities.

3. Understanding the storytelling functions (experiential, explanatory, validating and prescriptive) is a critical part of the storytelling method. It helps the researcher put the story in functional context along with an historical and social context.

4. Knowledge of storytelling functions also helps the researcher overcome any preconceptions they bring to the study. Researchers need to realize the reason they are interpreting a story as well as why the story is being told.

5. Researchers need to be aware that storytellers often place themselves in the story as the hero. Once again realizing the function of the story can help understand the motivation of the storyteller.

6. Sometimes a story may be told in different ways. In the classic 1950 film Rashomon, multiple storytellers recall a crime in very different ways. In each case they are motivated by their own self-interest (IMDb). The researcher needs to be aware of this possibility and needs to place the stories in social, historical, and functional context. Knowledge of the functions of stories is helpful to the researcher once again.

7. The researcher must recognize that interaction with participants changes stories to some degree. We describe four story activities (reacting, matching, eliciting, and collaborating) that researchers can use to obtain stories.

The story elements, mechanisms, functions, and activities all play a part in the storytelling method.

\section{CONCLUSION}

For too long, IS researchers have been immersed in minutiae when conducting interviews, examining metaphors, and observing organizations. In doing so they often willfully disregard the whole story in favor of structured fragments. Many methods facilitate gazing at the trees, rather than marveling at the forest. IS researchers can gain useful insights into organizational practices surrounding information systems and their socially constructed meaning by using the qualitative research method of storytelling. IS researchers can use storytelling to engage organizational participants in reacting to stories, matching one story told by recounting another, eliciting a new story, and collaborating in interpreting organizational stories about information systems use, problems, systems development, and systems adoption, as well as the strategic use of information systems.

In developing our storytelling method, we developed a typology where stories can be described on a continuum from practical to philosophical, and from normative to descriptive. We propose that stories 
are rooted in myths, and so can be usefully discussed in a typology of four powerful functions: experiential, explanatory, validating, and prescriptive.

Understanding the purpose of an organizational story (through elaboration of the myth) is not sufficient, however. Stories follow certain patterns and contain many elements told in a customary way. The researcher using storytelling as a research method must also be fully aware of the telling of the story (through vividness that resonates with well-known myths and fables) and the order in which it is told (through the use of episodes). These three mechanisms, along with the importance of appreciating the story as a whole rather than a sum of its parts, emphasize why using storytelling as a research method differs from other types of narrative analysis.

Information systems researchers need effective research methods like storytelling that heighten their awareness and understanding of how information systems and their users, managers, and developers are interacting in organizations. These insights enable IS researchers to interpret the meaning of organizational stories and how they are told. Stories have structure and purpose and researchers can begin to examine the stories they hear for patterns and commonalities.

While many standard research methods afford brief glimpses of information systems and the relationships among several organizational actors, storytelling presents an intuitively appealing, rich, and relatively unexplored method in IS that can unveil insights that are often unavailable through the use of other, traditional methods.

Traditional methods often result in customary framing of analysis and codification of results that actively militate against, or at least methodologically inhibit creativity in interpretation. Information systems researchers using storytelling are in many ways liberated from the constraints of framing imposed by traditional methods, and thus may infuse their studies of stories with fresh insight.

A story that resonates is reiterated over and over, told to many people (not just researchers) and often handed down to generations (in organizations, among teams, and even to outsiders such as customers and suppliers). The story as a whole, its meaning, its purpose, its reach, and its effectiveness has rarely been addressed by researchers in IS. It is for these reasons that this paper calls for IS researchers to embrace storytelling and in doing so to recognize how storytelling can become a powerful way to gain an understanding of information systems in organizations.

\section{Footnote}

${ }^{1}$ The authors thank these master storytellers, the playwrights we have met in the last five years, without whom we could not have written this paper: Woody Allen, David Auburn, Frank Blocker, Charles Busch, Jez Butterworth, Ethan Coen, Mike Daisey, Christopher Durang, Brian Hargrove, Jeffrey Hatcher, Bill Irwin, David Javerbaum, Tony Kushner, David Lindsay-Abaire, David Mamet, Tarell Alvin McCraney, Martin McDonagh, Denis O’Hare, Terrance McNally, Richard Nelson, Suzan-Lori Parks, David Pittu, James Rado, Paul Rudnick, Sarah Ruhl, Gabriel Shanks, and Lucy Thurber.

${ }^{2}$ The authors thank the editor who was a true collaborator on this paper. 


\section{REFERENCES}

Alvarez, R. \& Urla, J. (2002) "Tell Me a Good Story: Using Narrative Analysis to Examine Information Requirements Interviews During and ERP Implementation," The DATA BASE for Advances in Information Systems, Vol 33 No 1, pp 38-52.

Belk, R. W., \& Tumbat, G. (2005) “The Cult of Macintosh,” Consumption, Markets \& Culture, Vol 8 No 3, pp 205-217.

Berman, P. (1995) “Harry's a Great Storyteller,” Forbes, Vol 155 No 5, 02/27, pp 112-115.

Barker, R. T. \& Gower, K. (2010) “Strategic Application of Storytelling in Organizations," Journal of Business Communication, Vol 47 No 3, July, pp 295-312.

Boje, D. M., (1991) "The Storytelling Organization: A Study of Story Performance in an OfficeSupply Firm," Administrative Science Quarterly, Vol 36, pp 106-126.

Boland, R. J. \& Schultze, U. (1995) From Work to Activity: Technology and the Narrative of Progress. In W. J. Orlikowski, G. Walsham, M. R. Jones, \& J. I. DeGross (Eds.), Information Technology and Changes in Organizational Work, pp 308-323. London: Chapman \& Hall.

Boland, R. J. \& Schultze, U. (1996) "Narrating Accountability: Cognition and the Production of the Accountable Self," in Accountability: Power, Ethos, and the Technologies of Managing, R. Munro \& R. Mouritsen (Eds.) London: International Thompson Business Press.

Bormann, E. (1972) "Fantasy and Rhetorical Vision: the Rhetorical Criticism of Social Reality," Quarterly Journal of Speech Vol 58, pp 396-407.

Brown, A.D. (1998) "Narrative, Politics and Legitimacy in an IT Implementation," Journal of Management Studies, Vol. 35 No 1, pp 35-58.

Bruner, J. S. (1990) Acts of Meaning, Harvard University Press, Cambridge, MA.

Campbell, J. (1964) The Masks of God, Vol. 3: Occidental Mythology, Penguin Books USA Inc., New York.

Checkland, P. (1999). Soft Systems Methodology in Action: A 30-year retrospective, John Wiley \& Sons, New York.

Chreim, S. (2005) "The Continuity-Change Duality in Narrative Texts of Organizational Identity," Journal of Management Studies, Vol 43 No 3, 567-593.

Creswell, J. W. (2007) Qualitative Inquiry \& Research Design, Sage Publications, Thousand Oaks, CA.

Denning, P. J. (2004) “The Field of Programmers Myth," Communications of the ACM, Vol 47 No 7, 07, pp 15-20.

Denning, S. (2000) The Springboard: How Storytelling Ignites Action in Knowledge-Era Organizations, Butterworth-Heinemann, Woburn, MA.

Désilets, A. (2008) “Tell Me a Story,” IEEE Software, Vol 25 No 2, Mar, pp 14-15.

Doty, W. G. (2004) Myth: A Handbook, Greenwood Press, Westport, CT. 
Dube, L. \& Robey, D. (1999) "Software Stories: Three Cultural Perspectives on the Organizational Practices of Software Development," Accounting, Management, and Information Technologies Vol 9, pp 223-259.

Ellingsen, G. (2003) "Knowledge Work in Hospitals" in Global and Organizational Discourse about Information Technology, E. Wynn, E. Whitley, M. Myers, J. DeGross (Eds.), Kluwer Academic Publishers, Boston, pp 466-484.

Fincham, R. (2002) "Narratives of Success and Failure in Systems Development," British Journal of Management, Vol 13, pp 1-14.

Frohman, D. (2006) “Leadership Under Fire,” Harvard Business Review, Vol 84 No 12, 12, pp 124131.

Gabriel, Y. (2000), Storytelling in Organizations: Facts, Fictions, and Fantasies, Oxford University Press, New York.

Gillard, H., Mitev, N. \& Scott, S. (2007) "ICT Inclusion and Gender: Tensions in Narratives of Network Engineer Training,” Information Society, Vol 23 No 1, Jan, pp 19-37.

Gioia, D. A. \& Pitre, E. (1990) "Multiparadigm Perspectives on Theory Building," Academy of Management Review, Vol 15, No 4, pp 584-602.

Grover, V. \& Ramanlal, P. (1999) "Six Myths of Information and Markets: Information Technology Networks, Electronic Commerce, and the Battle for Consumer Surplus," MIS Quarterly, Vol 23 No 4, 12, pp 465-495.

Hanson, K. (2004) “Keeping a Sense of Community Alive," Strategic Communication Management, Vol 8 No 4, Jun, pp 6-7.

Higgs, M. \& Rowland, D. (2010)"Emperors with Clothes on: The Role of Self-Awareness in Developing Effective Change Leadership,” Journal of Change Management, Vol 10 No 4, 12, pp 369-385.

Hodgett, S. \& Deneulin, S. (2009) On The use of Narratives for Assessing Development Policy, Public Administration Vol 87, No 1, pp 65-79.

IMDb, Rashomon, accessed at http://www.imdb.com/title/tt0042876/, January 10, 2012.

Jacobson, I. , Booch, G. \& Rumbaugh, J. (1999) The Unified Software Development Process, Addison-Wesley, Reading, MA.

James, C. H. \& Minnis, C. (2004) “Organizational Storytelling: It Makes Sense,” Business Horizons Vol 47 No 4, July-August, pp 23-32.

Johnson, K. N. (2008) "Storytelling \& Software Testing," http://www.testingreflections.com/node/view/6700 accessed 22 March 2011.

Kaplan, B. \& Maxwell, J.A. (1994) "Qualitative Research Methods for Evaluating Computer Information Systems," in Evaluating Health Care Information Systems: Methods and Applications, J.G. Anderson, C.E. Aydin \& S.J. Jay (Eds.), Sage, Thousand Oaks, CA, pp 4568.

Kelly, C. \& Zak, M. (1999) "Narrativity and Professional Communication: Folktales and Community Meaning.” Journal of Business and Technical Communication, Vol 13, pp 297-317.

Kendall, J.E. \& K.E. (1985) "Development, Application and Enrichment of STROBE: Refinement of an Observational Tool for the Information Analyst," in Research Methods in Information 
Systems, by E. Mumford, R. Hirschheim, G. Fitzgerald, \& A. T. Wood-Harper (Eds.), Elsevier Science Publishers B. V., Amsterdam, pp 119-129.

Kendall, J.E. \& Kendall, K.E. (1993) "Metaphors and Methodologies: Living Beyond the Systems Machine,” MIS Quarterly, Vol 17 No 2, pp 149-171.

Kendall, J.E. \& Kendall, K.E. (1994) "Metaphors and their Meaning for Information Systems Development, European Journal of Information Systems, Vol 3 No 1, pp 37-47.

Kendall, J.E. \& Kendall, K.E. (1995) “The Impact of Using Hypertext-based Information Systems on Organizational Narrative: Changing the Structure of Stories in D.M. Olson (Ed.)," Proceedings of the Third International Meeting of the Decision Sciences Institute, Puebla, Mexico.

Kendall, J. E., Kendall, K.E. \& Kah, M. M. O. (2007) "Examining Virtual Organizations Using Fantasy Theme Analysis: A Study of ICT Policy Advisors' Discourse about Developing Countries," JITTA (Journal of Information Technology Theory \& Application) Vol 8, No 2, pp $1-20$.

Kendall, J. E. \& Kerola, P. (1994) “A Foundation for the Use of Hypertext-Based Documentation Techniques," Journal of End User Computing, Vol 6 No 1, pp 4-14.

Kendall, K. E. \& Kendall, J.E. (1984a) "Structured Observation of the Decision-Making Environment: A Validity and Reliability Assessment," Decision Sciences, Vol 15 No 1, pp 107-118.

Kendall, K. E. \& Kendall, J.E. (1984b) "STROBE: A Structured Approach to Observation of the Decision-Making Environment,” Information \& Management, Vol 7 No 1, pp 1-11.

Kendall, K. E. \& Kendall, J.E. (2011) Systems Analysis and Design, Eighth Edition, Prentice Hall, Upper Saddle River, NJ.

Kendall, K. E., Kendall, J. E., \& Lee, K. C. (2005) "Understanding Disaster Recovery Planning through a Theatre Metaphor: Rehearsing for a Show that Might Never Open," Communications of the Association for Information Systems, Vol 16, Article 51. http://aisel.aisnet.org/cais/vol16/iss1/51 accessed 22 March 2011.

Kendall, K. E. \& Losee, R. D. (1986) "Information System FOLKLORE: A New Technique for System Documentation,” Information \& Management, Vol 10 No 2, 1986, pp 103-111.

Klein, H. K. \& Myers, M. D. (1999) “A Set of Principles for Conducting and Evaluating Interpretive Field Studies in Information Systems," MIS Quarterly, Special Issue on Intensive Research, Vol 23 No 1, pp 67-93.

Kuechler, W.L. \& Vaishnavi, V. (2006) "So, Talk to Me: The Effect of Explicit Goals on the Comprehension of Business Process Narratives,” MIS Quarterly, Vol 30 No 4, pp 961-979.

Lee, A. S. (2010) "Retrospect and Prospect: Information Systems Research in the Last and Next 25 Years," Journal of Information Technology, Vol 25, pp 336-348.

Levy, S. J. (1994) “Interpreting Consumer Mythology,” Marketing Management, Vol 2 No 4, Spring94, 1994, pp 4-9.

Lieblich, A., Tuval-Mashiach, R., \& Zilber, T. (1998) Narrative Research, Sage Publications, Inc., Thousand Oaks, CA.

Livingston, J. S. (1969) “Pygmalion in Management,” Harvard Business Review, Vol 47 No 4, Jul, pp 81-89. 
MacKenzie, D. and Wajcman, J., (Eds.) (1998) The Social Shaping of Technology, 2nd ed. Open University Press, Buckingham, UK.

Macaulay, K. D., Yue, A. R. \& Thurlow, A. B. (2010) “Ghosts in the Hallways: Unseen Actors and Organizational Change,” Journal of Change Management, Vol 10 No 4, 12, pp 335-346.

Mainiero, L. A. (1994) "Getting Anointed for Advancement: The Case of Executive Women," Academy of Management Executive, Vol 8 No 2, 05, pp 53-64.

Mascarenhas, S., Dias, J., Prada, R. \& Paiva, A. (2010) “A Dimensional Model for Cultural Behavior in Virtual Agents,” Applied Artificial Intelligence, Vol 24 No 6, 07, pp 552-574.

Mintzberg, H. (1972) “The Myths of MIS,” California Management Review, Vol 15 No 1, Fall72, 1972, pp 92-97.

Misa, T.J., Feenberg, A., \& Brey, P. (Eds.) (2003) Modernity and Technology, MIT Press, Cambridge, MA.

Mitroff, I. I. \& Kilmann, R. H. (1975) "Stories Managers Tell: A New Tool for Organizational Problem Solving,” Management Review, Vol 64 No 7, pp 18-28.

Moen, T. (2006) "Reflection on the Narrative Research Approach," International Journal of Qualitative Methods, Vol 5 $\quad$ No 4, Article 5, http://www.ualberta.ca/ iiqm/backissues/5 4/pdf/moen.pdf accessed 4 March, 2011.

Moisander, J. \& Eriksson, P. (2006) "Cooperative Narratives of Information Society: Making up the Mobile Consumer Subject,” Consumption, Markets and Culture, Vol 9 No 4, pp 257-275.

Moody, J.W., Blanton, J. E. \& Cheney, P.H. (1998) “A Theoretically Grounded Approach to Assist Memory Recall During Information Requirements Determination," Journal of Management Information Systems, Vol 15 No 1, pp 79-98.

Myers, M. D. "Qualitative Research in Information Systems," MIS Quarterly (21:2), June 1997, pp. 241-242. MISQ Discovery, archival version, June 1997, http://www.misq.org/supplements/. MISQ Discovery, updated version, last modified: November 12, 2011 www.qual.auckland.ac.nz

Myers, M. D. \& Newman, M. (2007) "The Qualitative Interview in IS Research: Examining the Craft," Information and Organization Vol 17, pp 2-26.

Ohara, S. C. \& Cherniss, M. (2010) "Storytelling at Jupiter Networks Connects a Global Organization to the Values and Behaviors of Success," Global Business and Organizational Excellence, Vol 29 No 5, pp 31-39.

Patton, M. Q. (2002) Qualitative Research \& Evaluation Methods, 3rd edition. Sage Publications Inc., Thousand Oaks, CA, pp 339-427.

Pentland, B. (1999) "Narrative Methods in Collaborative Systems Research," Proceedings of the 32nd Hawaii International Conference on Systems Sciences, Hawaii: IEEE Computer Society, pp 19.

Pinch, T. \& Bijker, W. (1984) "The Social Construction of Facts and Artifacts: or How the Sociology of Science and the Sociology of Technology Might Benefit Each Other," Social Studies of Science, Sage, Vol 14 No 3, pp 399-441.

Powers, R. F. \& Dickson, G. W. (1973) “MisProject Management: Myths, Opinions, and Reality," California Management Review, Vol 15 No 3, Spring73, pp 147-156. 
Ready, D. A. (2002) "How Storytelling Builds Next-Generation Leaders," MIT Sloan Management Review, Vol 43, No 4, pp 63-69.

Sabherwal, R. \& Robey, D. (1993) “An Empirical Taxonomy of Implementation Processes Based on Sequence of Events in Information System Development," Organization Science, Vol 4 No 4, pp 548-576.

Seffah, A. \& Metzker, E. (2004) "The Obstacles and Myths of Usability And Software Engineering," Communications of the ACM Vol 47 No 12), pp 71-76.

Schultze, U. \& Avital, M. (2011) "Designing Interviews to Generate Rich Data for Information Systems Research,” Information and Organization, Vol 21 No 1, pp 1-16.

Shim, J.P., Shin, Y. B., \& Nottingham, L. (2002). "Retailer Web Site Influence on Customer Shopping: Exploratory Study on Key Factors of Customer Satisfaction," Journal of the Association for Information Systems, Vol 3 No 3, pp 53-76.

Shin, D. (2006) "Effective Design in the Development of Public Information Infrastructure: A Social Constructionist Approach," Information Polity, Vol 11, pp 85-100.

Shultis, R. (1964) “Playscript - A New Tool Accountants Need,” NAA Bulletin, Vol 45 No 12, pp 310.

Silva, L. \& Backhouse, J. (2003). "The Circuits-Of-Power Framework For Studying Information Systems. Journal of the Association for Information Systems,” Vol 4 No 14, pp 236-294.

Silverman, L. I. (2004) “Strategic Storytelling,” Association Management, Vol 56, No 11, 41-48.

Smillie, K. (2010) "Notes on Canadian Computing, 1950s," IEEE Annals of the History of Computing, Vol 32 No 2, Apr, pp 58-83.

Social construction of technology (SCOT) (n.d.) On Social construction of technology STS wiki. Retrieved from http://www.stswiki.org/index.php?title=Social_construction_of_technology_\%28SCOT\%29, January 6, 2012.

Stewart, T. A. \& Kaufman, D. C. (1995) “Getting Real about Brainpower,” Fortune, Vol 132 No 11, 11/27, pp 201-203.

Swap, W., Leonard, D., Shields, M., \& Abrams, L. (2001) "Using Mentoring and Storytelling to Transfer Knowledge in the Workplace,” Journal of Management Information Systems, Vol 18 No 1, pp 95-114.

Tan, F. \& M.G. Hunter (2003) "Using Narrative Inquiry in a Study of Information Systems Professionals," in 36th Hawaii International Conference on System Sciences, Hawaii: IEEE Computer Society, p 235.

Tichy, N. (1997) The Leadership Engine, Harper Business, New York.

Vergin, R. C., And A. J. Grimes. (1964) "Management Myths and EDP," California Management Review, Vol 7 No 1, Fall64, pp 59-70.

Vlachoutsicos, C. A. (2011) "How to Cultivate Engaged Employees," Harvard Business Review, Vol 89 No 9, 09, pp 123-126.

von Bertalanffy, L. (1968). General System Theory, G. Braziller, New York.

Walsham, G. (1993) Interpreting Information Systems in Organizations, Wiley, Chichester, pp. 4-5. 
Weick, K. E. \& Browning, L.D. (1986) "Argument and Narration in Organizational Communication, Journal of Management," Vol 12 No 2, pp 243-259.

Whelan, G., and C. O'Gorman. (2007) "The Schumpeterian and Universal Hero Myth in Stories of Irish Entrepreneurs," Irish Journal of Management, Vol 28 No 2, 10, 2007, pp 79-107.

Young, J. (2004) "Joseph Campbell - A Scholar's Life," The Center for Story and Symbol, http://www.folkstory.com/ accessed on 22 March 2011. 


\section{APPENDIX}

\begin{tabular}{|c|c|}
\hline $\begin{array}{l}\text { Klein \& Myers (1999) } \\
\text { Principles for Interpretive } \\
\text { Field Research }\end{array}$ & $\begin{array}{l}\text { How the Kendall \& Kendall Storytelling as a Methodology Paper } \\
\text { Addresses each of the Seven Klein and Myers Principles }\end{array}$ \\
\hline $\begin{array}{l}\text { 1. The Fundamental Principle } \\
\text { of the Hermeneutic Circle }\end{array}$ & $\begin{array}{l}\text { The storytelling method described in this article reiterates the fundamental } \\
\text { principle of the Hermeneutic Circle that individual parts of the narrative } \\
\text { cannot be understood without understanding the whole narrative. Kendall } \\
\& \text { Kendall suggest that in order to better understand the } 18 \text { distinct } \\
\text { elements of a story a researcher needs to appreciate the story as a whole. In } \\
\text { turn, the whole story helps the researcher understand what the story } \\
\text { elements mean. }\end{array}$ \\
\hline $\begin{array}{l}\text { 2. The Principle of } \\
\text { Contextualization }\end{array}$ & $\begin{array}{l}\text { In this article, Kendall \& Kendall articulate four functions of storytelling } \\
\text { and the storyteller typically sets the story. While interpretation of stories } \\
\text { require the interpreter to be aware of the social and historical context, } \\
\text { Kendall \& Kendall also recognize that interpreters should be aware of the } \\
\text { functional context. }\end{array}$ \\
\hline $\begin{array}{l}\text { 3. The Principle of Interaction } \\
\text { Between the Researchers and } \\
\text { the Subjects }\end{array}$ & $\begin{array}{l}\text { The storytelling method recognizes that the storytellers, not just the } \\
\text { researchers, serve as interpreters and analysts. In this article, Kendall and } \\
\text { Kendall suggest four activities a researcher can undertake to help elicit } \\
\text { stories that are accurate and detailed. They are reacting, matching, eliciting, } \\
\text { and collaborating. }\end{array}$ \\
\hline $\begin{array}{l}\text { 4. The Principle of Abstraction } \\
\text { and Generalization }\end{array}$ & $\begin{array}{l}\text { This principle compels the researcher to relate theoretical abstractions and } \\
\text { generalizations to the details experienced or collected by the researcher. } \\
\text { Kendall \& Kendall identify } 18 \text { elements common in complex stories, then } \\
\text { assess these to conclude that each of these contribute to three cognitive } \\
\text { mechanisms (vividness, elaboration, and episodic) that together make a } \\
\text { story memorable and enduring. }\end{array}$ \\
\hline $\begin{array}{l}\text { 5. The Principle of Dialogical } \\
\text { Reasoning }\end{array}$ & $\begin{array}{l}\text { Each researcher may approach storytelling differently based on their } \\
\text { knowledge of myths and folklore as well as prior experience in } \\
\text { organizations. Storytellers, however, tell stories because they believe the } \\
\text { stories have a function. Kendall \& Kendall recognize that identification of } \\
\text { the intended function may cause the researcher to revise their theoretical } \\
\text { preconceptions. }\end{array}$ \\
\hline $\begin{array}{l}\text { 6. The Principle of Multiple } \\
\text { Interpretations }\end{array}$ & $\begin{array}{l}\text { The same story can be told by different storytellers from conflicting } \\
\text { viewpoints. The storytellers may be motivated by their own self-interest. } \\
\text { Kendall \& Kendall recognize that there may be multiple interpretations of } \\
\text { the same story. }\end{array}$ \\
\hline 7. The Principle of Suspicion & $\begin{array}{l}\text { Since storytellers often place themselves as the hero in a story, multiple } \\
\text { storytellers may be in conflict with one another. In this case, Kendall \& } \\
\text { Kendall recommend that the researcher needs to reexamine the context and } \\
\text { scrutinize which function is intended. }\end{array}$ \\
\hline
\end{tabular}

Table 5. The storytelling method observes the principles for interpretive research. 